\title{
DNA2 Gene
}

National Cancer Institute

\section{Source}

National Cancer Institute. DNA2 Gene. NCI Thesaurus. Code C117091.

This gene is involved in the replication and repair of DNA. 